\title{
PENTINGNYA SIKAP TOLERANSI DI MASA PANDEMI COVID-19
}

\author{
Frila Damayanti Hasana $^{\bowtie}$, Supriyono, Dadi Mulyadi Nugraha
}

Universitas Pendidikan Indonesia

\begin{tabular}{l}
\hline Info Artikel \\
\hline Sejarah Artikel: \\
Disubmit: September \\
2021 \\
Direvisi: Oktober 2021 \\
Diterima: November \\
2021 \\
\hline Keywords: \\
Tolerance; Covid-19; \\
Attitude
\end{tabular}

\begin{abstract}
Abstrak
Penelitian ini bertujuan untuk mengetahui bagaimana sikap toleransi masyarakat akibat adanya virus baru yang membuat kehidupan kita berubah. Dengan adanya virus ini, masyarakat tidak bisa menjalankan fungsi sosialnya dengan baik. Metode yang digunakan dalam artikel ini adalah metode penelitian kualitatif. Teknik pengumpulan data yang digunakan adalah melalui pembagian kuisioner. Pembagian kuisioner diberikan kepada masyarakat umum sebanyak 52 orang. Hasil penelitian ini menunjukkan bahwa 1) toleransi adalah sikap menghargai satu sama lain walaupun setiap orang di dunia memiliki perbedaan baik itu suku, ras, atau apapun.2) dengan adanya sikap toleransi yang kita terapkan dalam kehidupan sehari-hari, masyarakat bisa lebih menghargai terhadap perbedaan yang ada di lingkungan sosialnya dan juga sikap toleransi dapat mencegah terjadinya perpecahan di masyarakat. 3) Adanya virus corona dapat membuat masyarakat berhenti menjalankan fungsinya dalam kehidupan sosial. Hal ini dapat berpengaruh kepada sikap toleransi dan solidaritas yang ada di masyarakat. 4) sikap toleransi yang ada di masyarakat pada masa pandemi cukup tinggi.
\end{abstract}

\begin{abstract}
This study aims to find out how the community's tolerance attitude is due to the new virus that has changed our lives. With this virus, people cannot carry out their social functions properly. The method used in this article is a qualitative research method. The data collection technique used is through the distribution of questionnaires. The distribution of questionnaires was given to the general public as many as 52 people. The results of this study indicate that 1) tolerance is an attitude of respect for each other even though everyone in the world has differences, be it ethnicity, race, or whatever. 2) with the attitude of tolerance that we apply in everyday life, people can appreciate more towards the differences that exist in the social environment and also the attitude of tolerance can prevent divisions in society. 3) The existence of the corona virus can make people stop carrying out their functions in social life. This can affect the attitude of tolerance and solidarity that exists in society. 4) the attitude of tolerance that exists in society during the pandemic is quite high.
\end{abstract}

(C) 2021 Universitas Negeri Semarang

$\begin{array}{lr}\text { Alamat korespondensi: } & \text { ISSN 2252-7133 } \\ \text { Komplek Buciper J1.Bina Darma No.4 } & \text { E-ISSN 2548-4648 } \\ \text { E-mail: friladamayanti87@gmail.com } & \end{array}$




\section{PENDAHULUAN}

Indonesia ialah bangsa yang mempunyai berbagai macam ras, suku, agama, dan juga bahasa. Indonesia dikenal sebagai bangsa yang mempunyai sikap toleransi tinggi. Tetapi meskipun begitu, masih ada saja masyarakat yang tidak mau untuk menerapkan sikap toleransi dalam kehidupannya. Masih banyak masyarakat yang melakukan diskriminasi atau membeda-bedakan. Untuk mencapai masyarakat yang damai, perlu yang dinamakan sikap toleransi. Sikap toleransi itu pun dapat berupa toleransi atar budaya, toleransi antar umat beragama, dan toleransi berbahasa.

\section{Toleransi}

Menurut Kamus Besar Bahasa Indonesia (KBBI) toleransi adalah sifat atau sikap toleran, batas ukur untuk penambahan atau pengurangan yang masih diperbolehkan, penyimpangan yang masih dapat diterima dalam pengukuran kerja. Toleransi adalah sikap, perilaku atau sifat menenggang berupa menghargai serta memperbolehkan suatu pendirian, pendapat, pandangan, kepercayaan maupun yang lainnya yang berbeda dengan pendapat kita sendiri menurut W. J. S. Poerwadarminto dalam (Muawanah, 2018). Adapun secara terminologi, toleransi yaitu pemberian kebebasan kepada sesama manusia atau kepada sesama warga masyarakat untuk menjalankan keyakinan atau mengatur hidupnya dan menentukan nasibnya masing-masing, selama dalam menjalankan dan menentukan sikapnya itu tidak melanggar dan tidak bertentangan dengan syarat-syarat atas terciptanya ketertiban dan perdamaian dalam masyarakat, menurut Umar Hasyim dalam (Muawanah, 2018).

Dari beberapa pendapat diatas, dapat disimpulkan bahwa toleransi adalah sikap saling menghargai dan menghormati satu sama lain tanpa membeda-bedakan ras, suku, juga bahasa. Toleransi sudah seharusnya menjadi sikap yang harus dilakukan untuk mengormati satu sama lain dan menghargai segala perbedaan yang setiap orang miliki. Meski kelihatannya sederhana, tetapi toleransi mempunyai pengaruh yang besar dalam kehidupan bermasyarakat. Jika toleransi tidak kita terapkan dan jalankan dalam kehidupan sehari-hari, mungkin yang akan terjadi adalah masyarakat Indonesia akan terpecah belah dan menjadi bangsa yang hancur.

Prinsip- prinsip dalam toleransi yaitu rasa penghormatan, penerimaan dan penghargaan atas keragaman budaya dunia yang kaya, berbagai bentuk ekspresi diri, dan berbagai cara menjadi manusia. Toleransi disebut juga kerukunan dalam perbedaan. Suatu sikap atau perilaku manusia yang tidak menyimpang dari aturan, dimana seseorang bisa menghargai atau menghormati setiap tindakan yang dilakukan orang lain (Hamidah, 2015).

Upaya dalam pendidikan karakter untuk mengembangkan nilai toleransi dan peduli sosial dalam semua kalangan sudah sepatutnya dilakukan di berbagai kegiatan dan lingkungan. (Sari, 2016). Contohnya di lingkungan sekolah sikap toleransi antar sesama dan peduli sosial wajib dilakukan dalam kehidupan sehari-hari. Sekolah merupakan salah satu pendidikan yang paling penting dalam kehidupan. Di sekolah diwajibkan diajarkan nilai-nilai yang akan membawa kehidupan kearah yang lebih baik. Diperlukan upaya terus menerus yang dapat mengarahkan siswa untuk menerapkan sikap toleransi, sehingga mereka dapat menjadikan sikap tersebut menjadi sikap yang patut dikembangan dalam lingkungan masyarakat.

Manfaat dilakukannya toleransi dalam kehidupan bermasyarakat antara lain adalah dapat menciptakan keharmonisan, kerukunan dalam bermasyarakat, menciptakan rasa kebersamaan, dan akan terciptanya kedamaian, rasa tenang serta rasa aman dalam kehidupan bermasyarakat. Contohnya, jika di suatu daerah ada seseorang yang berbeda suku, berbeda agama, dan memiliki perbedaan budaya dengan kita, kita harus menghormatinya dan berusaha untuk menghargai perbedaan yang kita miliki agar tercipta perdamaian. Toleransi dapat menjadi masalah yang serius dan berdampak negatif jika masyarakatnya tidak menyadari bagaimana pentingnya menjalankan toleransi.

Toleransi beragama adalah sikap menghargai satu sama lain yang berhubungan dengan keyakinan yang dipercayai seseorang. 
Dalam hal ini, setiap orang berhak memilih siapa dan apa yang diyakininya. Umat manusia yang beragama harus berusaha menerapkan toleransi beragama dalam kehidupan sehari-hari sehingga walaupun ada perbedaan keyakinan diantara mereka, kerukunan yang mereka jalani tetap terjaga. Toleransi antar umat beragama yakni pada saat tiap- tiap umat beragama menghormati serta menghargai ketika umat agama yang lainnya sedang melakukan ibadah. Hidup secara berdampingan, saling menghormati serta menghargai agama lain merupakan wujud dari toleransi beragama. Dalam konteks sosial budaya dan agama, toleransi ialah perilaku yang melarang serta menghindari terdapatnya diskriminasi ataupun perilaku membedabedakan dalam suatu kelompok warga (Fitriani, 2020). Contoh toleransi beragama yang sudah dilakukan di Indonesia yaitu di Desa Ngargoyoso, kaki Gunung Lawu yakni terdapat tiga tempat ibadah berdampingan yaitu masjid, gereja, dan pura.

Toleransi berbudaya adalah sikap menghargai satu sama lain akan adanya perbedaan budaya yang dimiliki. Karena Negara Indonesia adalah Negara multicultural, maka dari itu pasti masyarakatnya mempunyai banyak budaya yang berbeda. Sebagai bangsa Indonesia yang memiliki sikap toleransi yang tinggi, kita harus menghargai adanya perbedaan budaya yang terjadi dalam masyarakat. Adapun yang dimaksud dari toleransi berbahasa adalah ketika kita berbicara kepada orang lain suah menjadi kewajiban untuk kita menggunakan bahasa yang baik dan benar. Jika kita akan berbicara sebaiknya difikirkan dulu kata yang akan kita ucapkan akan menyinggung perasaan orang lain atau tidak.

Beberapa dampak positif yang kita dapatkan jika toleransi diterapkan dalam kehidupan bermasyarakat adalah membangun rasa nasionalisme, membangun rasa persaudaraan antar masyarakat, dan mempermudah proses musyawarah yang akan terjadi dalam kehidupan masyarakat. Perilaku yang dapat kita lakukan contohnya adalah menghormati orang lain, tidak memaksakan kehendak kita kepada orang lain, menghargai pendapat orang lain, dan tidak memandang perbedaan fisik dan psikis seseorang ketika bersosialisasi. Dalam kehidupan bermasyarakat, pastinya kita bertemu banyak orang-orang yang baru dan memiliki banyak perbedaan dengan kita. Jika kita tidak menerapkan sikap toleransi dalam kehidupan, maka kita akan sulit dalam bersosialisasi. Dnegan bertoleransi, maka kita akan dapat menjalani kehidupan yang memiliki banyak perbedaan.

Toleransi merupakan salah satu perilaku yang dilakukan untuk mengimplementasikan nilai-nilai pancasila dalam kehidupan sehari-hari. Toleransi beragama dapat menjadi pengimplementasian sila ke satu yaitu Ketuhanan yang Maha Esa yang mencerminkan bahwa pemeluk agama Tuhan yang berbeda-beda dapat hidup dengan tentram serta saling berdampingan satu sama lain, sehingga akan tercipta kerukunan antar umat beragama. Sila kedua yang berbunyi Kemanusiaan yang adil dan beradab bermakna bahwa semua manusia yang hidup berhak diperlakukan sama dan tidak ada yang boleh membeda-bedakan manusia lainnya berdasarkan suku, agama, ekonomi, dan warna kulit karena kita semua adalah makhluk ciptaan tuhan dan mempunyai hak dan kewajiban yang sama. Sila ketiga berbunyi Persatuan Indonesia. Sikap toleransi terhadap sila ini adalah dengan kita sebagai rakyat Indonesia yang baik sudah seharusnya menjaga persatuan dan kesatuan. Sila keempat yang berbunyi kerakyatan yang dipimpin oleh hikmat kebijaksanaan dalam permusyawaratan perwakilan. Sikap toleransi yang dapat mencerminkan sila ini adalah dengan setiap mengambil keputusan, sudah selayaknya kita melakukan mufakat dalam menyelesaikan masalah dan tidak memaksa pendapat kita kepada orang lain. Sila kelima yang berbunyi keadilan sosial bagi seluruh rakyat Indonesia. Sikap toleransi yang dapat mencerminkan sila tersebut adalah selaku berusaha menolong atau membantu orang lain sesuai kemampuan kita, menghargai hasil karya orang lain, menghormati hak dan kewajiban orang lain (Yani et al., 2020).

\section{Virus Covid-19}


Dewasa ini, dunia mengalami pandemi virus covid-19. Adanya virus ini menimbulkan banyak perubahan yang terjadi pada tatanan hidup manusia. Semua itu bisa kita lihat dari segi pendidikan, ekonomi, maupun sosial budaya. Semua kehidupan masyarakat berubah secara drastis. Banyak masyarakat yang kehilangan pekerjaan akibat adanya pandemi ini. Virus covid-19 ini adalah virus yang berbahaya karena sifatnya yang menular. Penularan virus ini diprediksi terjadi melalui droplet dan kontak dengan orang yang terinfeksi virus ini kemudian virus dapat masuk ke dalam mukosa yang terbuka. Suatu analisis dilakukan dengan tujuan mengukur laju penularan berdasarkan masa inkubasi, gejala dan durasi antara gejala dengan pasien yang diisolasi. Analisis tersebut menghasilkan bahwa penularan dari 1 pasien ke pasien lain sekitar ke 3 orang di sekitarnya, tetapi kemungkinan penularan di masa inkubasi menyebabkan masa kontak pasien ke prang sekitar lebih lama sehingga risiko jumlah kontak tertular dari 1 pasien mungkin dapar lebih besar. (Davies, 2002) Maka dari itu pemerintah mengadakan PSBB (Pembatasan Sosial Berskala Besar) yang berfungsi untuk memutus rantai virus tersebut. Akibat dari PSBB ini pun semua masyarakat dunia berdiam diri dirumah dan melakukan semua kegiatannya dari rumah. Kegiatan beragama pun diharuskan dilakukan di rumah. Maka dari itu, perlu adanya sikap toleransi masyarakat di masa pandemic covid-19 ini.

Terkadang kita tidak mampu mengontrol rasa curiga, takut dalam merespon isu corona ini. Hal ini dapat berpengaruh merusak hubungan sosial dengan individu lain. Bisa kita saksikan di berbagai tempat, terkadang terjadi tindakantindakan yang memaksakan kehendak yang menggerus semangat toleransi dam solidaritas sosial di masa pandemi. Sebenarnya, rasa cemas yang ada pada diri kita atas adanya wabah virus ini adalah hal yang wajar. Kita berupaya untuk memutus mata rantai penyebaran virus corona ini karena kepanikan dan ketakutan. (Rasyid, 2020).

Dengan adanya virus covid-19 di masyarakat, menyebabkan masyarakat tidak bisa menjalankan fungsi sosialnya dalam masyarakat. Halangan untuk bersosialisasi itu nyata adanya. Adanya ketakutan dan kekhawatiran akan virus ini membuat masyarakat memberi ruang atau jarak dalam berkehidupan sosial. Hal ini jika dibiarkan mungkin akan memutus hubungan antar individu dalam sebuah kelompok. Terdapat banyak kejadian yang mengatakan bahwa beberapa pasien virus corona ini terkadang bebas keluar rumah dan seakan tidak memerdulikan kesehatannya. Hal ini yang menjadi ketakutan banyak orang ketika ia akan bersosialisasi atau keluar rumah. Terkadang ada orang yang egois dan tidak memikirkan orang lain. Contohnya adalah seorang pasien covid yang merasa dirinya sudah sembuh dan keluar rumah padahal ia akan menjadi sumber yang menularkan virus ini ke banyak orang. Maka dari itu perlu adanya sikap toleransi antar individu dnegan keadaan kita sekarang ini.

\section{METODE}

Metode yang digunakan dalam artikel ini adalah metode penelitian kualitatif. Dimana penelitian ini dimaksudkan untuk untuk melakukan generalisasi terhadap fenomina sosial yang tengah kita alami. Pengumpulan data dilakukan dengan memberi kuisioner kepada masyarakat umum. Kuisioner diberikan kepada sebanyak 52 responden. Objek dalam penelitian ini adalah bagaimana sikap toleransi yang ada di masyarakat terhadap adanya perubahan baru dari kebiasaan masyarakat. Analisis data yang digunakan dalam penelitian ini yaitu dimulai dari tahap pengumpulan data, penyaringan data, dan penarikan kesimpulan.

\section{PEMBAHASAN}

Dari kuisioner yang telah dibagikan, terdapat 52 responden yang mengisi dan berasal dari berbagai kalangan. Dalam survey ini responden diberikan 11 pertanyaan.

Tabel 1. Jawaban menenai Pengertian Toleransi

$$
\text { Pengertian Toleransi }
$$


1. Toleransi adalah saling menghargai dan menghormati walaupun berbeda suku ras dan agama

2. Saling menghargai dan menghormati (tidak membeda bedakan)

3. Toleransi adalah sikap dimana kita harus saling hormat menghormati sesama umat di dunia

4. Menghargai antar sesama, tak membandingkan nya melalui suku adat ras budaya maupun agama, Merangkul bukan memukul, memeluk bukan menusuk, mencintai bukan menghianati

5. Toleransi adalah ketika kita dapat menghargai orang lain dan tidak memaksakan kehendak

6. Untuk saling menghormati dan menghargai perbedaan, baik antarindividu maupun kelompok. Untuk menghadirkan perdamaian dalam keberagaman, perlu menerapkan sikap toleransi. Toleransi yang dimaksud bukan sebagai jargon semata, tapi juga sebagai pandangan teoritis yang lebih serius

7. Toleransi adalah, sikap manusia untuk saling menghormati dan menghargai perbedaan, baik antarindividu maupun kelompok. Untuk menghadirkan perdamaian dalam keberagaman, perlu kita menerapkan sikap toleransi

Sumber: Data primer, 2021

Dalam pertanyaan pertama peneliti memberikan pertanyaan "apakah anda tahu arti dari toleransi?" dan tabel diatas adalah jawaban dari beberapa responden. Istilah toleransi berasal dari bahasa Latin dari kata "Tolerare" yang berarti dengan sabar membiarkan sesuatu. Pengertian toleransi adalah suatu sikap atau perilaku manusia yang mengikuti aturan, di mana seseorang dapat menghargai, menghormati terhadap perilaku orang lain (Bakar, 2015). Berdasarkan kutipan tersebut dan hasil pelitian dapat disimpulkan bahwa arti dari toleransi adalah sikap menghargai satu sama lain walaupun setiap orang di dunia memiliki perbedaan baik itu suku, ras, atau apapun. Setiap manusia yang ada dan hidup di dunia ini pasti mempunyai perbedaan yang sangat beragam.
Adanya keberagaman tersebut diharapkan semua manusia dapat hidup dengan rukun dan menerapkan sikap saling menghargai dan menghormati satu sama lain.

Pertanyaan kedua yang peneliti ajukan adalah "Apakah toleransi merupakan hal yang penting dalam kehidupan bermasyarakat?" semua responden menjawab Ya. Toleransi adalah salah satu hal yang penting dalam kehidupan bermasyarakat. Manfaat dari toleransi antara lain adalah agar terciptanya keharmonisan dalam masyarakat, tidak terjadi perpecahan dalam masyarakat, dan tidak adanya diskriminasi. Seperti yang disebutkan dalam jurnal yang berjudul "Pentingnya Pendidikan Untuk Tanamkan Sikap Toleran di Masyarakat" dalam jurnal tersebut disebutkan bahwa dengan ditanamkan sikap toleransi di dalam setiap masyarakat dapat membentuk warga negara yang dapat mewujudkan suatu tujuan bersama dalam kehidupan berbangsa dan bernegara (Muawanah, 2018).

Pertanyaan ketiga yang peneliti ajukan adalah "menurut anda apakah toleransi dapat menjadi alat pemersatu bangsa?" semua responden menjawab Ya. Dengan adanya toleransi, masyarakat bisa lebih menghargai perbedaan yang ada dan hal tersebut dapat menjadi dasar dari kehidupan bermasyarakat untuk menghindari perpecahan. Selain itu, adanya sikap toleransi juga dapat membuat hubungan antarmasyarakat menjadi lebih erat. Indonesia memiliki agama yang beragam. Setiap agama pun mengajarkan bahwa sikap toleransi adalah hal yang penting untuk dilakukan di kehidupan sehari-hari. Seperti yang disebutkan dalam jurnal yang berjudul Kerukunan dan Toleransi Antar Umat Beragama dalam Membangun Keutuhan Negara Kesatuan Republik Indonesia (NKRI), disebutkan manfaat dari adanya kerukunan antar negara contohnya kerukunan antar umat beragama adalah agar agama dapat menjadi alat pemersatu bangsa yang akan menciptakan stabilitas dan kemajuan Negara (Nazmudin, 2018). Para responden yang mengisi kuisioner ini menjawab bahwa sebanyak $88,5 \%$ (46 orang) sudah menerapkan sikap 
toleransi dalam kehidupan sehari-hari dan 11,5\% (6 orang) kadang-kadang.

Toleransi dapat menjadi implementasi sila-sila pancasila. Berdasarkan hasil penelitian, dapat disimpulkan bahwa sebanyak 44,2 \% (23 orang) menjawab sila ke-3; 30,8 \% (16 orang) menjawab sila ke-2; 13,5\% (7 orang) menjawab sila ke-1; 9,6\% (5 orang) menjawab sila ke-1; dan sisanya $1,9 \%$ (1 orang) menjawab sila ke-4.

Dewasa ini, terdapat virus baru yang muncul yaitu virus covid-19. Wabah virus corona ini menjadi hal yang harus dihadapi bagi semua umat manusia. Dengan adanya pandemi virus ini, semua masyarakat berubah pola hidupnya. Semua tempat yang dapat menyebabkan keramaian ditutup. Yang membuat masyarakat memiliki kekhawatiran tinggi adalah karena virus ini dapat menular. Dalam penelitian ini diajukan pertanyaan "Jika di lingkungan anda terdapat seorang pasien covid-19, apa yang akan anda lakukan? "sebanyak 98,1 \% (51 orang) menjawab akan mendukungnya dan $1,9 \%$ (1 orang) menjawab mendiamkannya. Alasan dari mereka yang menjawab mendukungnya adalah 1) Karena lebih baik mendukung nya, obat terbaik dari covid adalah kebahagiaan dan suasana hati yg baik. Menurut saya. Jika mendiamkannya dan menjauhinya dalam artian tidak peduli. Maka akan menyebabkan mental down kepada si penderita covid, 2) Karna saya suka bertoleransi dan itulah bentuk toleransi, 3) karena covid bukan sesuatu yang dijadikan kita alasan untuk membenci seseorang, musibah dari maha kuasa yang seharusnya kita lakukan mensuport sesuai dgn protokol kesehatan covid 19,dan lain-lain. Sementara 1 orang yang menjawab mendiamkannya, alasan ia adalah karena tidak ingin terpapar jika ia keluar rumah.

Peneliti juga mengajukan pertanyaan terkait pasien covid-19 yaitu "Jika ada seorang pasien covid-19 berjalan-jalan keluar rumah, tidak memperdulikan kesehatannya, apa yang akan anda lakukan?" dapat dilihat bahwa sebanyak 92,3 5 (48 orang) memilih untuk menasihati dengan baik; 5,8 \% (3 orang) memilih memarahinya dan 1,9\% (1 orang) memilih untuk menjauhinya. Alasan responden yang memilih menasihatinya dengan baik antara lain 1) karena dengan menasehatinya dengan baik, mungkin dia akan mengerti dan sadar, 2) Sejujurnya jika jika kita melihat hak tersebut tentu saja respon kita akan marah. Akan tetapi sebaiknya hal tersebut kita tahan dan menasihatinya dengan baik saja. Karena ada banyak faktor mengapa dia melakukan hal demikian. Mungkin saja kurangnya edukasi mengenai protokol kesehatan, atau faktor lainnya,3) karna bisa merugikan orang yang ada disekitarnya, dengan cara menasehati kita bisa menggunakan media online tidak bertatap muka dengan pasien supaya tidak memperluas virus covid dan diharuskan isolasi, dan lain-lain. Responden yang memilih memarahinya dan menjauhinya mempunyai alasan yaitu 1) Karena, apa yang ia lakukan tidak menghormati orang lain yang sehat yang sudah susah payah menjaga protokol kesehatan mereka dengan benar, 2) Sebab saudara saya ada yang terkena covid karena ulah temannya yg acuh kepada prokes dan tidak percaya covid. dan menurut saya itu adalah hal yg sangat bodoh yang tidak bisa ditolerir lagi dengan nasihat, dan 3) Membahayakan warga sekitar.

Pertanyaan terakhir yang diajukan peneliti adalah "Jika anda bertemu dengan pasien covid yang sudah sembuh, apa yang akan anda lakukan?" dapat dilihat bahwa sebanyak 98,1 \% (51 orang) menjawab bersikap biasa saja dan 1,9 \% (1 orang) menjawab tetap menjauhinya. Alasan para responden menjawab bersikap biasa saja karena mereka menganggap jika seorang pasien tersebut sudah sembuh, sudah tidak ada gunanya lagi untuk menjauhinya. Yang harus kita lakukan adalah mendukungnya dan merangkulnya agar tidak merasa rendah diri.

\section{SIMPULAN}

Dapat disimpulkan bahwa arti dari toleransi adalah sikap menghargai satu sama lain walaupun setiap orang di dunia memiliki perbedaan baik itu suku, ras, atau apapun. Dengan adanya toleransi, masyarakat bisa lebih menghargai perbedaan yang ada dan hal tersebut dapat menjadi modal penting untuk menghindari perpecahan yang akan terjadi di masyarakat. Sikap toleransi masyarakat pada era pandemic covid-19 ini masyarakat mempunyai sikap 
toleransi yang cukup tinggi. Mereka tidak membeda-bedakan seseorang yang terkena virus ini dan memilih untuk mensupportnya.

\section{DAFTAR PUSTAKA}

Bakar, A. (2015). Konsep Toleransi Dan Kebebasan Beragama. Toleransi, $7(2), \quad 123-131$ https://doi.org/10.24014/trs.v7i2.1426

Davies, P. D. O. (2002). Multi-drug resistant tuberculosis. CPD Infection, 3(1), 9-12.

Fitriani, S. (2020). Keberagaman dan Toleransi Antar Umat Beragama. Analisis : Jurnal Studi Keislaman, 20(2), 179-192.

Hamidah, S. (2015). TOLERANSI PERGURUAN PENCAK SILAT (Pagar Nusa, Kera Sakti dan PSHT). 11-31. http://etheses.uinmalang.ac.id/
Muawanah. (2018). Pentingnya Pendidikan untuk Tanamkan Sikap Toleran di Masyarakat. Jurnal Vijjacariya, 5(1), 57-70. https://osf.io/vqgj4/

Nazmudin, N. (2018). Kerukunan dan Toleransi Antar Umat Beragama dalam Membangun Keutuhan Negara Kesatuan Republik Indonesia (NKRI). Journal of Government and Civil Society, 1(1), 23. https://doi.org/10.31000/jgcs.v1i1.268

Sari, Y. M. (2016). Pembinaan Toleransi Dan Peduli Sosial Dalam Upaya Memantapkan Watak Kewarganegaraan (Civic Disposition) Siswa. Jurnal Pendidikan Ilmu Sosial, 23(1), 15-26. https://doi.org/10.17509/jpis.v23i1.2059

Yani, F., Darmayanti, E., Studi, P., Hukum, I., Hukum, F., Potensi, U., \& Pancasila, P. (2020). Implementasi Nilai- Nilai Pancasila Melalui. 2(1), 48-58. 